\title{
An examination of the national road-safety programs in the ten world's leading countries in road safety
}

\author{
Victoria Gitelman • Limor Hendel • Roby Carmel • \\ Shlomo Bekhor
}

Received: 6 June 2012 / Accepted: 14 June 2012 / Published online: 12 July 2012

(C) The Author(s) 2012. This article is published with open access at SpringerLink.com

\begin{abstract}
Purpose This study examined the national road safety programs carried out by the ten world's leading countries in road safety, aiming to identify the most effective interventions that contributed to safety progress in those countries and to consider the possibilities of their application in Israel. Method The best-performing countries were selected from European and other developed countries, using general safety indicators and the rate of road safety improvement achieved recently. The program documents and related reports published in the countries were screened aiming to sum up safety problems in the countries examined, safety interventions recommended for implementation by the countries' programs and evidence of the efficiency of those interventions.

Results Detailed classifications of safety problems and measures/interventions implemented by the countries' programs were produced. Evidence of the efficiency of safety interventions was collected in terms of associated accident reductions and the scope of measures' implementation
\end{abstract}

\footnotetext{
V. Gitelman $(\bowtie) \cdot$ L. Hendel $\cdot$ R. Carmel Ran Naor Road Safety Research Center, Technion - Israel Institute of Technology, Technion City, Haifa 32000, Israel e-mail: trivica@technion.ac.il

L. Hendel

e-mail: limorh@technion.ac.il

R. Carmel

e-mail: robyc@technion.ac.il

\section{S. Bekhor}

Faculty of Civil and Environmental Engineering,

Technion - Israel Institute of Technology,

Technion City, Haifa 32000, Israel

e-mail: sbekhor@technion.ac.il
}

during the program's performance. The study demonstrated a high similarity of main safety problems characteristic for the majority of leading countries, and for Israel. Thus, the summaries of safety interventions adopted by those countries were applicable for addressing similar problems in local conditions. Most safety interventions associated with the countries' safety progress over the last decade came from the well-recognized areas of infrastructure and enforcement, whereas for some common safety problems, e.g. motorcyclist injury, driving fatigue, elderly vulnerability, prominent solutions are lacking.

Conclusion The research findings can serve as a basis for developing a new national program for promoting road safety in a country.

Keywords Road safety $\cdot$ National program $\cdot$ Typical problem $\cdot$ Intervention

\section{Introduction}

Road accidents incur significant human, social and financial costs. According to the World Health Organization, every day, more than 3,000 people in the world die in road accidents [38], while the global financial cost of road accidents is estimated at 518 billion dollars a year [18]. Moreover, according to global estimations, by the year 2020, road accidents will reach third place among ten leading death causes in the world [39]. In light of this tragic data, many countries around the world search for measures and interventions aiming to reduce the road accidents' burden.

Over the last decade, a remarkable decrease in the number of road traffic fatalities was observed in many advanced countries $[7,26]$, in which usually national road safety programs were applied. According to international experience 
$[14,34,36]$, development and implementation of a national road safety program constitutes a key component in the country safety management policy that contributes to raising awareness to the road safety field, building partnerships to tackle the problems and focusing the intervention efforts on the issues required. Today, both European and world-wide organizations encourage countries to develop and implement national road safety programs as a background condition for systematic work on promoting road safety $[3,36,38]$. In a more general context, currently the international research seeks to define essential components of effective road safety management $[32,33]$, where national road safety program is well-recognized as one of them.

This study intended to examine the national road safety programs (NRSP) that were carried out in the ten world's leading countries in road safety, in order to identify the most effective interventions that contributed to improved safety in those countries and to examine the possibilities of their application in Israel. The topic of NRSP is not new for Israel where one of the first NRSP was developed in the 1990s [22]; and the latest NRSP was adopted by the government in the mid 2000s [6]. The study was initiated by the National Road Safety Authority, based on the reasonable assumption that learning from the experience of other countries on treating road accidents can contribute to road safety in Israel by means of including these interventions in the development of new safety programs in Israel. Such an assumption is common in road safety work, where many reports summarize goodpractice experiences on various safety-related issues (e.g. $[24,36,41])$. However, the difference of the current study was in a more purposeful definition of its framework: a detailed reviewing of national road safety programs of the best-performing countries aimed at creating a comprehensive list of safety interventions that were adopted by a significant part of those countries and, according to the available evidence, probably contributed to their road safety success. It was believed that adopting similar interventions by a future Israeli NRSP may improve the program's potential in reducing road accident injury and save resources needed in the course of the program's development.

The study was carried out mostly in 2009 (the final report was published in the middle of 2010-[20]) and, therefore, based on data and publications accessible then. However, the main value of the study can be seen in the rational of the analysis performed and its general findings which might be of interest for other countries seeking to develop a NRSP.

\section{The study approach: An overview}

The study included three major phases as shown in Fig. 1. First, publications of European and other international organizations were reviewed in order to collect data on

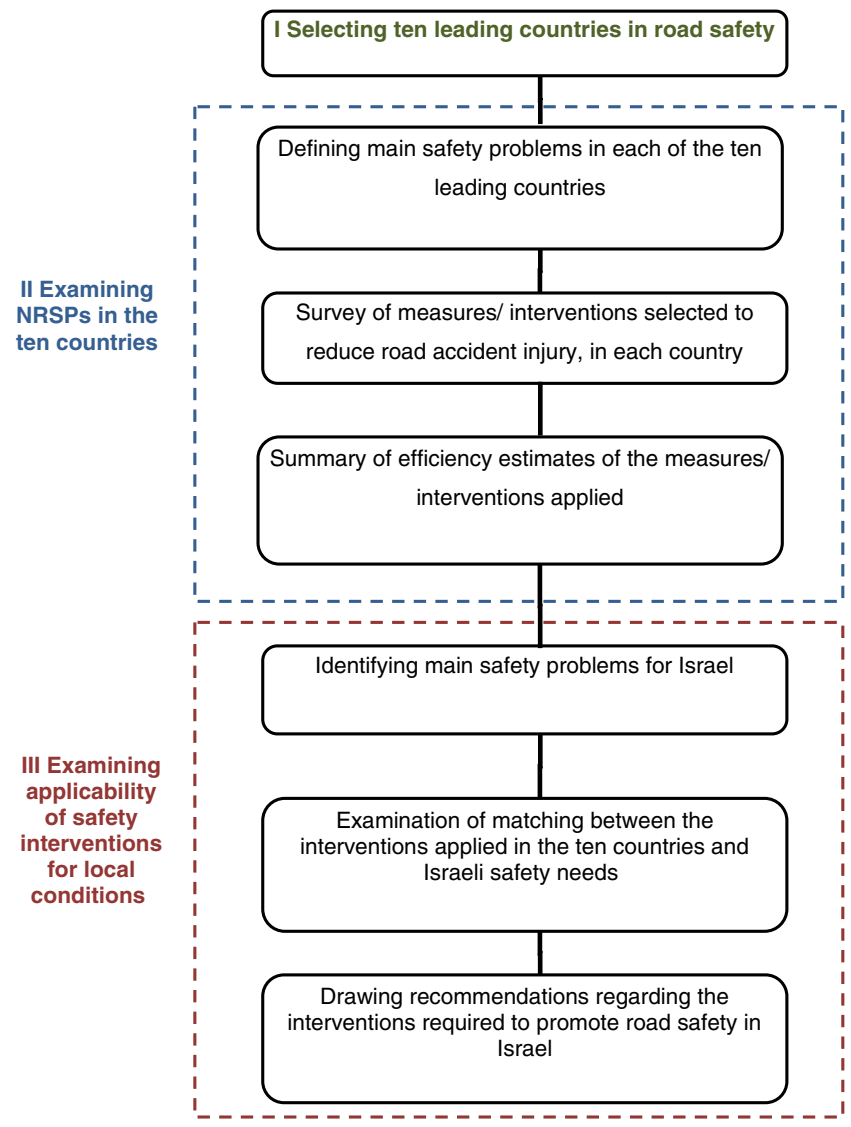

Fig. 1 The study phases

countries' safety progress. The ten leading countries in road safety were selected from the European and other advanced countries, using general safety indicators and the rate of road safety improvement achieved recently.

In the second phase, the NRSPs of the ten countries selected were explored in detail, based on the programs' publications and related reports, published in these countries and internationally. The examination of the NRSP in each selected country, focused on three issues: (a) defining main safety problems of the country; (b) summarizing safety measures/ interventions implemented in the country to reduce road accidents; (c) collecting the efficiency estimates of interventions implemented during the NRSP performance.

According to international experience, a typical structure of an NRSP includes seven components [34]: (1) formulation of vision or philosophy (e.g. "Vision Zero" in Sweden or "Sustainable Safety" in the Netherlands); (2) problem analysisassessing the road safety level in the country, including international comparisons, identifying at-risk populations and critical safety issues, examining the over-time trends; (3) targets setting; (4) developing the program's components - selecting safety measures and interventions; (5) performing economic evaluations of the program's potential in reducing casualties/ accidents; (6) program's approval and implementation; (7) monitoring and assessing the program's progress. 
The NRSP publications mostly include details on components $1-5$, while the economic evaluation component is relatively rare. The program implementation component usually does not appear in the form of systematic publications, except for annual reports on specific activities (e.g. the number of speed cameras activated; the number of roundabouts constructed, etc.) that can be found in selected countries only. However, systematic monitoring of the safety level-changes in the number of road traffic casualties and accidents - exists in all advanced countries, and, sometimes, includes also tracking selected behaviors (use of safety belts, speeding, etc.). Hence, in order to understand what has been performed in the framework of the NRSP, one can focus on two of the program's components: main safety problems identified in the country (component 2 ) and safety interventions selected for implementation (component 4), while the information regarding the extent of implementation of different measures and their effectiveness should be obtained from other publications (not from the program itself), such as: internal progress reports; position papers; country reports to international organizations; evaluation studies of research institutes, although such publications are not produced on a regular basis. However, countries with better safety performance (e.g. Sweden, the Netherlands, United Kingdom, Norway) usually publish more evaluation reports on various safety interventions and safety programs as a whole.

In addition, due to high awareness, in the advanced countries, and the need for international collaboration, international organizations such as: Organisation for Economic Co-operation and Development (OECD), European Transport Safety Council (ETSC), the European Commission (EC)generate and distribute summaries of knowledge and international experience regarding various safety issues. Thus, prior to a detailed examination of the NRSPs in the selected countries, a review of the current international knowledge and experience regarding main safety problems and recommended safety interventions, was conducted.

In the third phase of the study, an examination of match between the interventions applied in other countries and Israeli safety needs was performed. This examination included: (a) identifying the main safety problems which are characteristic for Israel, (b) examining the interventions that were implemented in the ten countries addressing similar safety problems; (c) drawing recommendations regarding the interventions required to promote road safety in Israel. The safety problems characteristic for Israel were compared with those found in other countries (on the second step of the study), while for each safety problem common to Israel and the leading countries, a list of safety interventions/measures applied for addressing this issue, in other countries, was examined. The interventions which were actually implemented in the other countries and, thus, contributed to the success of these countries in reducing road traffic casualties were recommended for implementation under Israeli conditions.

\section{Selecting the ten leading countries in road safety}

\subsection{Method}

The literature suggests various indicators to examine the level of road safety in a country [7, 19, 26, 44, 47]. Thus, in general, various methods can be developed to select ten leading countries in road safety. However, the selection is typically limited by data availability for the majority of countries compared. Moreover, comparability problems are still in place as to the definitions of road traffic injuries [8] and behaviors, while a common definition is applied, in most countries, for road traffic fatalities [25].

In this study, the conventional way of comparing safety levels of countries was applied, by using general safety indicators: number of road fatalities per population, vehicle fleet and kilometers-traveled. The three indicators allow pointing out the "safest" countries in terms of the risk of being killed in traffic accidents, related to various forms of exposure, and are recommended to be applied together in order to overcome the weaknesses of each of them [37].

An additional way of comparing country progress, which was applied in Europe over the last decade, is to examine over-time changes of a certain figure, e.g. the absolute numbers of road traffic fatalities in a country. For example, according to Jost et al. [28], the countries achieving the European Union (EU) goal of reducing the annual number of fatalities by $50 \%$ between the years 2000 to 2010 , were France, Portugal and Luxembourg, which were characterized by an $8 \%-10 \%$ average annual reduction of fatalities in years 2001-2008.

Thus, to select ten leading countries in road safety, European and other developed countries were compared in terms of four indicators: (1) road fatalities per population, in 2008; (2) the average annual percentage change in road deaths, in 2001-2008; (3) road fatalities per million passenger cars, in 2006; (4) road fatalities per 10 billion passengerkilometers traveled, in 2006. The data for these figures were collected from publications of international organizations, i.e. Jost et al. [28]; IRTAD [26]; OECD/ECMT [35], while data availability dictated a comparison year for each indicator considered. Following the study objective, the leading countries were selected compared to Israel's position according to each one of the indicators considered.

\subsection{Results}

Figure 2 presents the fatality rate per population in each country, in 2008, versus the average annual percentage change 
in road traffic deaths in the years 2001-2008. The EU averages of these two measures (blue lines - based on [28]) divide the figure into four quarters, where best-performing countries are in the quarter of "lower mortality, higher reduction". As Israel also belongs to that quarter, to recognize countries in a better position compared to Israel, two red lines were drawn through Israel's values. As a result, three countries were found (Switzerland, Germany, the Netherlands) which are safer than Israel according to both indicators, while several more countries demonstrated advantages compared to Israel according to one of the indicators-all the selections are marked by dashed ovals on Fig. 2.

The second examination (Fig. 3) compared the countries in terms of the number of road fatalities per million passenger cars and per 10 billion passenger cars-km traveled, both in 2006. Similar to the previous case, two red lines were drawn through the Israeli values, revealing a group of countries in better position compared to Israel, i.e. with lower values of both indicators (see a dashed oval on Fig. 3).

To summarize both examinations, a country definitely selected in a certain case received the score " 1 ", where one partially fitting received the score " 0.5 ". Subsequently, two weightings were performed given equal and unequal weights to each examination. Both weightings produced similar results, recognizing eight leading countries with highest final scores: the Netherlands, Germany, Switzerland, France, United
Kingdom, Sweden, Norway and Belgium (Luxembourg was omitted from the list as a country not having a NRSP). Further, from the pair of Finland and Denmark with equal scores, Finland was selected as having better safety indicators than those of Denmark. Similarly, from the pair of Spain and Portugal with equal scores, Portugal was selected due to a significantly higher percentage of annual fatality reduction. Hence, the ten leading countries in road safety performance selected for further examination were: the Netherlands (NL), Germany (DE), Switzerland (CH), France (FR), the United Kingdom (UK), Sweden (SE), Norway (NO), Belgium (BE), Finland (FI), and Portugal (PT).

\section{A summary of international knowledge and experience}

International knowledge and experience regarding essential safety problems and interventions are available through reviews of international bodies, which are frequently published as background documents for policy developments. Thus, prior to the analysis of NRSPs of the countries selected, a summary of such publications was provided-EC [9]; ETSC [14, 16]; Jost et al. [28]; OECD/ITF [36]. In addition, the findings from the European project SUPREME [24] were examined, which summarized road safety interventions that were considered as best EU experience.

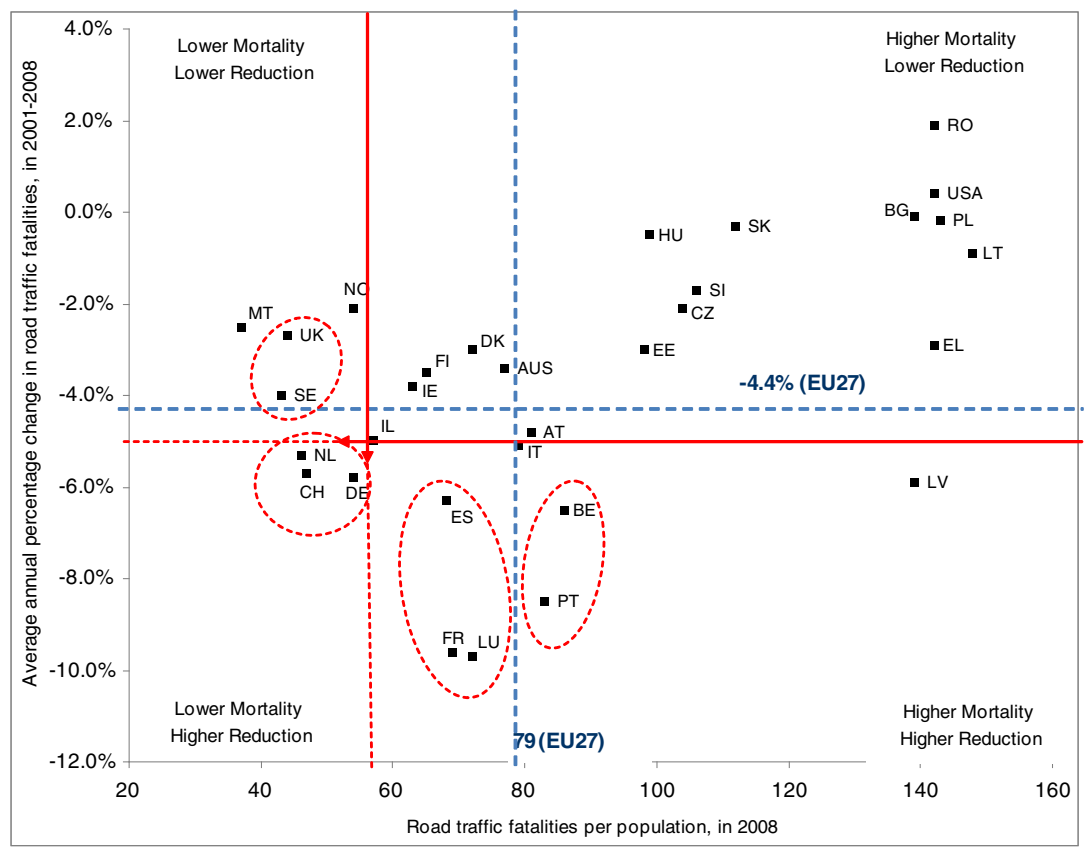

Fig. 2 Fatality rate per population, in 2008, versus the average annual percentage change in road traffic fatalities in 2001-2008, in advanced countries, compared to Israel. Source: [28]. For USA and Australia: fatality rates for 2006 (from [26]), percentage change in fatalities for 2004 (from [35]). Countries: AT - Austria, AUS - Australia, BE Belgium, CH - Switzerland, CZ - Czech Republic, DE - Germany,
DK - Denmark, EE - Estonia, EL - Greece, ES - Spain, FI - Finland, FR - France, HU - Hungary, IE - Ireland, IT - Italy, LT - Lithuania, LU - Luxembourg, LV - Latvia, MT - Malta, NL - Netherlands, NO Norway, PL - Poland, PT - Portugal, RO - Romania, SE - Sweden, SI Slovenia, SK - Slovakia, UK - United Kingdom and USA 
Fig. 3 Number of road fatalities per million passenger cars versus the number of road fatalities per 10 billion passenger-kilometers traveled, in 2006, in different countries, compared to Israel. Source: [35]. For Switzerland, Norway, USA and Australia, the indicator is per motor vehicle instead of passenger cars, based on IRTAD [26]

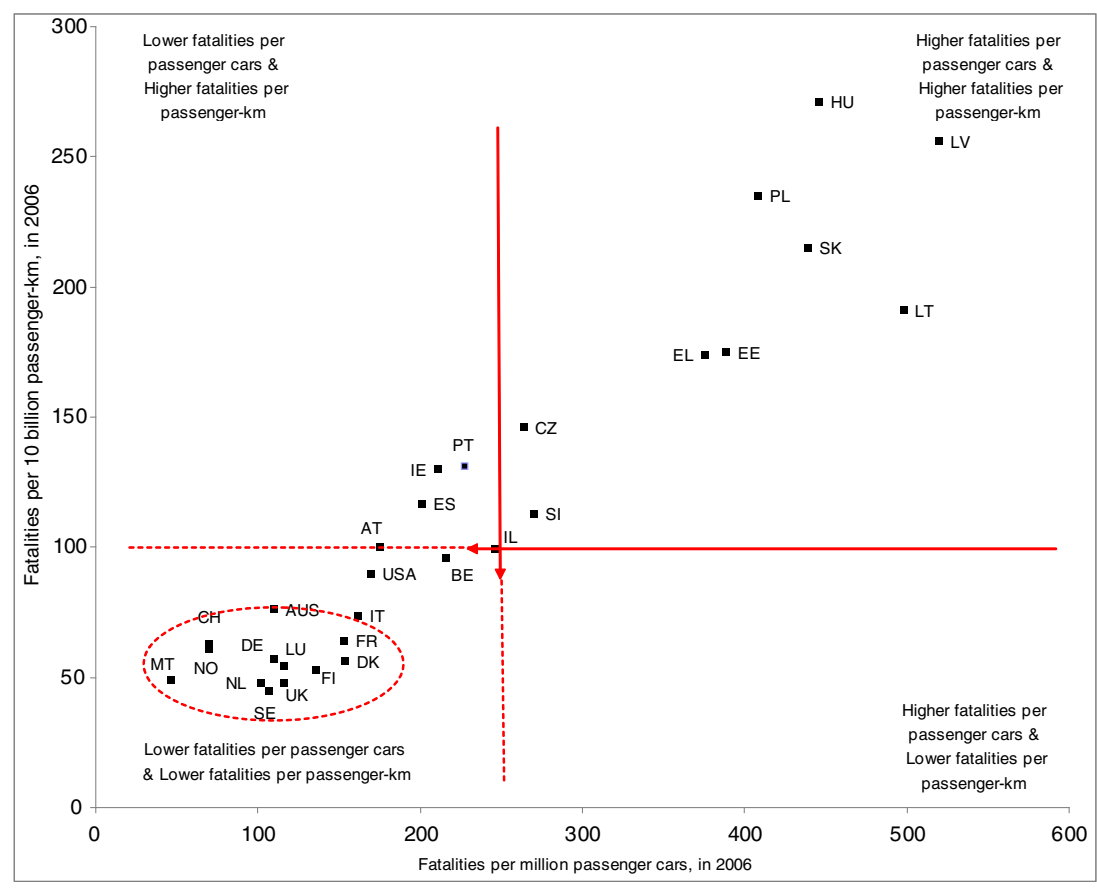

According to the summary, the main safety problems which advanced countries have dealt with over the past decade were:

- Unsafe behaviors of road users, with emphasis on speeding (excessive and inappropriate speeds), driving under the influence of alcohol or drugs, non-use of seatbelts or helmets;

- Unsafe infrastructure;

- Vulnerable road users: pedestrians, cyclists, motorcyclists, children and the elderly;

- Young drivers;

- Vehicle safety;

- Post-crash medical care.

The interventions and measures recommended for addressing these issues were:

- Improving road user behavior through massive enforcement backed up by legislation and penalties, education and publicity, and introducing new vehicle technologies;

- Improving road infrastructure through conducting safety audits and inspections, black-spot treatment, traffic calming, building roundabouts, providing forgiving roadsides;

- Improving safety of vulnerable road users, through a combination of vehicle improvements, infrastructure measures, educational programs, legislation, publicity and enforcement;

- Promoting safer vehicles, through increasing penetration rates of active and passive safety systems, distributing information to consumers;
- Promoting graduated driving licensing for young drivers, through legislation, education, training, enforcement and publicity;

- Improving emergency services and treatment of accident victims, through shortening arrival time of rescue services to the accident scene, training medical personnel, improving medical care on scene, adequate rehabilitation programs;

- Improving accident data collection, analysis and distribution through database development, establishing systems for linking hospital data and national road accidents statistics, in-depth investigation of accidents;

- Better safety management: using a systematic approach, specifying objectives, implementation and evaluation of interventions, resource requirements, achieving commitment of agencies and the public, regular monitoring for identifying problems and measuring progress towards achieving the goals.

The international summary suggests a general framework check-list for identifying typical safety problems and matching effective safety interventions, for a NRSP development.

\section{Detailed examination of the NRSPs of leading countries}

The characterization and analysis of the NRSPs in the selected countries were based on the national programs' documents published in these countries, together with country's 
self-reporting to international bodies, follow-up reports and other papers published during the programs' implementation. The information sources, for each country, were found through literature surveys, screening publications of international bodies and direct contacts with researchers working in the countries. For example, the list of information sources for the Netherlands included nine items, where two of themWegman and Aarts [43], Ministry of Transport, Public works and Water Management [31] - described the NRSP components; three more-ETSC [15], OECD/ECMT [35], IRTAD [26] - were the country's self-reports on the performance progress; and four others-Aarts et al. [1], Weijermars et al. [45], Wijnen et al. [46], Christoph [5]—were research studies on the effectiveness of program's interventions. Moreover, it was found that considering the countries' development over the last decade, two NRSPs are to be discussed, for each country: one started at the beginning of the decade (in the years 1997-2003) and an updated one started at the end of the decade, where some countries (e.g. the Netherlands, Norway, Finland) published the new NRSPs whilest others identified future directions in the accompanying reports.

Examining the NRSPs in each country focused on three issues: (a) defining main safety problems the country faced during the last decade and/or is facing today; (b) summarizing safety measures/interventions which were applied over the last decade and/or are recommended for implementation by current or future safety programs; (c) summarizing the efficiency estimates of interventions implemented by the NRSPs, in terms of their contribution to improved safety.

\subsection{Typical safety problems}

As expected, a considerable similarity was found between typical safety problems in most countries considered. Thus, to summarize the findings from different NRSPs, a uniform classification was applied. The safety problems were divided into eight areas: vulnerable populations, drivers, behaviors, infrastructure, vehicle conditions, information and knowledge, safety management, and rescue services, where each area included a further division into categories (specific safety problems). Figure 4 presents the classification and main safety problems common to the countries analyzed. In each area, the safety problems are ranked according to their frequency of appearance in the NRSPs of the ten countries, where the summaries are given for those programs that were carried out ("Last decade", left part of Fig. 4) and for existing and new ones ("Today", right part of Fig. 4). Beside each problem, in parentheses, the countries for which this issue appeared in their program are listed.

Figure 4 demonstrates the over-time changes in importance of selected safety problems, where among the most common safety problems in the ten countries appear:

- In the area of behaviors: speeding, driving under the influence of alcohol, nonuse of vehicle restraints, failure to comply with traffic laws, driving under the influence of drugs and medications, both over the past decade and in new programs;

- In the area of vulnerable populations: children and cyclists, over the past decade, when recently the focus has moved to motorcyclists, still together with children;

- In the area of drivers: young novice drivers, drivers with repeated offenses and all drivers were in the focus over the past decade, while recently the focus remained mostly on young novice drivers and drivers with repeated offenses;

- In the area of infrastructure: safety of urban streets, single-carriageway roads, design guidelines, roadside obstacles, over the past decade, while recently the focus remained mostly on single-carriageway roads and urban streets;

- In the area of vehicles: vehicle maintenance problems were common over the past decade, where today the emphasis is mainly on non-implementation of vehicle safety measures;

- In the remaining areas, no common problems were found for most countries, although, both in the past and today, four countries underlined the need for reducing arrival time of rescue services.

5.2 Safety interventions implemented to address the problems

The classification introduced also served as a basis for summing up safety measures/interventions recommended for implementation by the countries' NRSPs. For each safety problem defined, a list of treatments was composed, both for previous ("last decade") and current safety programs, where safety interventions are ranked according to their appearance frequency and, for each item, relevant countries are mentioned. Figures 5 and 6 present examples of such lists of interventions summarized for "Motorcycle" and "Urban streets" safety problems, respectively.

Based on the summaries produced, it was seen that the most common interventions implemented by the NRSPs in the past decade were:

- For "Speeding": camera-based speed enforcement (appeared in 10 countries); publicity campaigns emphasizing the relationship between speed and safety (in 5 countries); fine increase (in 4); legislation changes supporting automatic enforcement (in 3); 
Fig. 4 Safety problems presented in the NRSPs of the ten leading countries
Today
Children (8 - FI, SE, UK, NO, PT, CH, BE, DE)

- Cyclists (5 - FI, BE, UK, DE, NL)

- Mopeds (4 - BE, FR, PT, NL)

- Elderly (4 - NO, UK, FI, DE)

- Pedestrians (3 - UK, DE, PT)

- Motorcyclists (2 - PT, UK)
- Motorcyclists (9 - FR, FI, BE, DE, PT, UK, NO, CH, NL)

- Children (5 PT, FI, BE, CH, NO)

- Cyclists (4 - FR, CH, PT, NL)

- Pedestrians (3- CH, PT, NO)

- Elderly (3 - FI, BE, NL)

- Mopeds (2 - SE, NL)
Vulnerable

populations
- Young novice drivers (10 - FI, SE, BE, UK, FR, NO, DE, PT, CH, NL)

- Drivers with repeated offenses (7$\mathrm{FR}, \mathrm{FI}, \mathrm{BE}, \mathrm{DE}, \mathrm{NO}, \mathrm{PT}, \mathrm{UK})$

- All drivers (5 - DE, PT, UK, FI, NO)

- Professional drivers (4 - BE, DE, UK, FR)

\begin{tabular}{|c|c|c|}
\hline $\begin{array}{l}\text { - Speeding (10 - FI, SE, BE, UK, FR, NO, } \\
\text { DE, PT, CH, NL) } \\
\text { - Driving under the influence of alcohol } \\
(10-\mathrm{FI}, \mathrm{SE}, \mathrm{BE}, \mathrm{UK}, \mathrm{FR}, \mathrm{NO}, \mathrm{DE}, \mathrm{PT} \text {, } \\
\mathrm{CH}, \mathrm{NL}) \\
\text { - } \\
\text { Nonuse of vehicle restraints (9 - FI, } \\
\text { SE, UK, FR, NO, BE, PT, CH, NL) } \\
\text { - Failure to comply with traffic laws (8 - } \\
\text { SE, UK, NL, FR, FI, BE, DE, NO) } \\
\text { - Driving under the influence of drugs/ } \\
\text { medications (5 - FR, CH, PT, UK, DE) } \\
\text { - Driving fatigue (3 - NO, CH, UK) } \\
\text { Using cell-phone while driving (3 - BE, } \\
\text { DE, UK) }\end{array}$ & Behaviors & $\begin{array}{l}\text { - Speeding (10 - FI, SE, BE, UK, FR, NO, } \\
\text { DE, PT, CH, NL) } \\
\text { - Driving under the influence of alcohol } \\
(10-\mathrm{FI}, \mathrm{SE}, \mathrm{BE}, \mathrm{UK}, \mathrm{FR}, \mathrm{NO}, \mathrm{DE}, \mathrm{PT} \text {, } \\
\mathrm{CH}, \mathrm{NL}) \\
\text { - Nonuse of vehicle restraints (7 - FI, } \\
\text { UK, FR, NO, BE, PT, CH) } \\
\text { - Driving under the influence of drugs/ } \\
\text { medications (6 - UK, NO, BE, CH, NL, } \\
\text { FI) } \\
\text { - Failure to comply with traffic laws (5 - } \\
\text { NL, FR, DE, CH, PT) } \\
\text { - Driving fatigue (1 - NL) } \\
\text { - Using cell-phone while driving (0) }\end{array}$ \\
\hline $\begin{array}{l}\text { - Rural single-carriageway roads (10 - } \\
\text { FI, SE, BE, UK, FR, NO, DE, PT, CH, NL) } \\
\text { - } \text { PT, CH, NO, NL) } \\
\text { - } \text { Design guidelines (7 - SE, DE, PT, UK, } \\
\text { - Roadside obstacles (6 - FI, SE, FR, NL, } \\
\text { PT, DE) } \\
\text { - } \text { Motorways (3 - DE, PT, NL) } \\
\text { - } \text { Black-spots (2 - BE , NO) } \\
\text { - Saintenance problems (2 - PT, UK) } \\
\text { - Safety in tunnels (1 - CH) } \\
\text { - Collisions with animals (0) } \\
\text { - Railroad crossings (0) }\end{array}$ & Infrastructure & 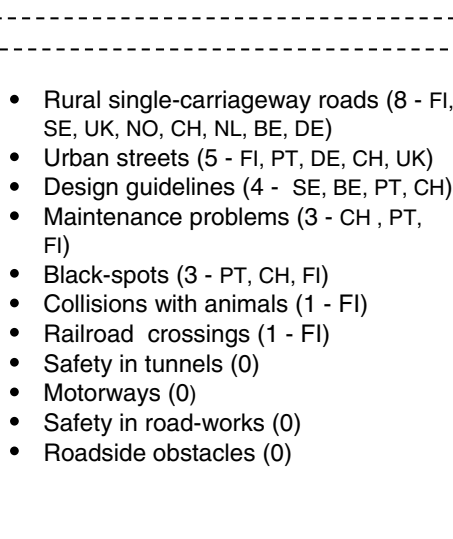 \\
\hline
\end{tabular}

- For "Nonuse of vehicle restraints": enforcement of safety belts' use and helmet wearing (in 7 countries) and publicity campaigns (in 6);

- For "Urban streets" (see Fig. 6): creating $30 \mathrm{~km} /$ $\mathrm{h}$ zones (in 6 countries); traffic calming measures (in 3 countries in the past decade and also in 3 updated programs), where other measures also include elements of traffic calming and/or separating vulnerable road users from vehicle traffic.

- For "Driving under the influence of alcohol": increased enforcement-performing breath tests on roadsides (in 6 countries); publicity campaigns (in 5); stricter punishment (in 5) and lowering the maximum legal blood alcohol concentration (BAC), from $0.8 \mathrm{~g} / 1$ to $0.5 \mathrm{~g} / 1$ (in 3 countries);

- For "Rural single-carriageway roads": building a physical separation between travel directions, i.e. " $2+2$ ", " $2+1$ " roads (in 4 countries) and other infrastructure improvements (in 3);

- For treating "Roadside obstacles": installing guardrails and removing roadside obstacles (in 5 countries);

- For "Children" as a vulnerable population group: safety education at schools (in 3 countries); 
Fig. 4 (continued)

\begin{tabular}{|c|c|c|}
\hline $\begin{array}{l}\text { - Vehicle maintenance problems (7 - } \\
\text { FI, NL, UK, FR, DE, PT, BE) } \\
\text { - Non-implementation of vehicle safety } \\
\text { measures (4 - UK, SE, DE, FI) } \\
\text { - Safety measures for heavy vehicles } \\
\text { (3 - CH, PT, UK) } \\
\text { - Limitations for heavy vehicles (2 - CH, } \\
\text { BE) }\end{array}$ & Vehicle & $\begin{array}{l}\text { - Non-implementation of vehicle safety } \\
\text { measures (7 - UK, NL, FI, BE, DE, } \\
\text { SE, CH) } \\
\text { - Vehicle maintenance problems (3 - } \\
\text { CH, FI, NL) } \\
\text { - Safety measures for heavy vehicles } \\
\text { (3- DE, NL, FI) } \\
\text { - Limitations for heavy vehicles (1 - FI) }\end{array}$ \\
\hline $\begin{array}{l}\text { - Accident information (2 - DE, SE) } \\
\text { - Knowledge of accidents causes (1 - } \\
\text { SE) }\end{array}$ & $\begin{array}{l}\text { Information and } \\
\text { knowledge }\end{array}$ & $\begin{array}{l}\text { Accident information (4 - FI, NL, SE, } \\
\mathrm{CH} \text { ) } \\
\text { - Knowledge of accidents causes (0) }\end{array}$ \\
\hline $\begin{array}{l}\text { - Distribution of tasks between } \\
\text { authorities ( } 3 \text { - UK, NL, BE) } \\
\text { - } \text { Authorities involvement }(1 \text { - PT) } \\
\text { - Increasing awareness }(1 \text { - SE) } \\
\text { - Capacity building (0) }\end{array}$ & $\begin{array}{c}\text { Safety } \\
\text { management }\end{array}$ & $\begin{array}{l}\text { - Distribution of tasks between } \\
\text { authorities ( } 3-\mathrm{CH}, \mathrm{Fl}, \mathrm{NL}) \\
\text { - Capacity building }(2-\mathrm{CH}, \mathrm{PT}) \\
\text { - Increasing awareness }(2-\mathrm{SE}, \mathrm{PT}) \\
\text { - Authorities involvement (1 - BE) }\end{array}$ \\
\hline $\begin{array}{l}\text { - Arrival time of rescue services (4 - PT, } \\
\mathrm{NL}, \mathrm{FI}, \mathrm{BE} \text { ) }\end{array}$ & $\begin{array}{l}\text { Rescue } \\
\text { services }\end{array}$ & $\begin{array}{l}\text { - Arrival time of rescue services (4 - FI, } \\
\mathrm{DE}, \mathrm{CH}, \mathrm{PT})\end{array}$ \\
\hline
\end{tabular}

- For "Young novice drivers": graduated driving license (in 5 countries) and stricter punishment for young driver offenses (in 4).

Regarding the "arrival time of rescue services", promoting eCall installations in vehicles appeared in two NRSPs in the past decade and in three new ones. However, for one of the most common problems among the countries- motorcyclists - a prominent solution was not found (see Fig. 5), while various measures were applied or suggested by different countries. Among other safety problems specified in the program's updates for which prominent interventions are lacking can be mentioned: the problem of "driving under the influence of drugs/medications"; "driving fatigue"; the elderly population.
Fig. 5 Summary of interventions included in the NRSPs of the ten countries for treating "Vulnerable populations - motorcyclists" safety problem

\begin{tabular}{|c|c|}
\hline Last decade & Current safety programs \\
\hline 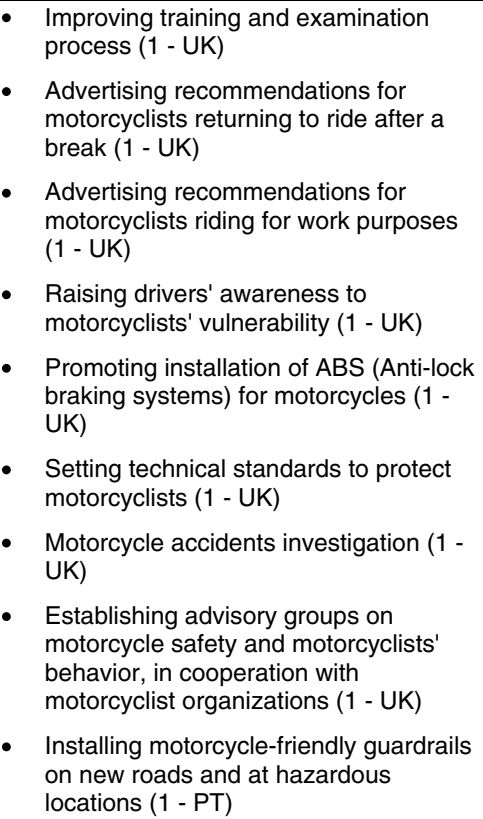 & $\begin{array}{l}\text { - } \begin{array}{l}\text { Strengthening the requirements for } \\
\text { driving motorcycle tests (2 - FI, CH) }\end{array} \\
\text { - } \quad \text { Improving training and examination } \\
\text { process (1 - PT) } \\
\text { - } \text { Motorcycle-friendly guardrails (2 - } \\
\text { PT, NL) } \\
\text { Initiative to require ABS-installation } \\
\text { for motorcycles (1 - DE) } \\
\text { Examining the possibility of raising } \\
\text { the threshold age for receiving a } \\
\text { motorcycle driver's license (1 - FI) } \\
\text { Graduated driving license for } \\
\text { motorcycles (1 - FI) } \\
\text { Enforcement of wearing helmets and } \\
\text { daytime running lights (1 - PT) } \\
\text { Strengthening sanctions for non- } \\
\text { wearing a helmet (1 - PT) } \\
\text { Campaigns for high-school } \\
\text { motorcyclists (1 - PT) }\end{array}$ \\
\hline
\end{tabular}


Fig. 6 Summary of interventions included in the NRSPs of the ten countries for treating "Infrastructure - urban streets" safety problem

\begin{tabular}{|c|c|}
\hline Last decade & Current safety programs \\
\hline $\begin{array}{ll}\text { - } & \text { Expanding and improving } 30 \mathrm{~km} / \mathrm{h} \\
& \text { zones }(6-\mathrm{SE}, \mathrm{UK}, \mathrm{PT}, \mathrm{NL}, \mathrm{BE}, \mathrm{DE}) \\
\text { - } & \text { Traffic calming ( } 3-\mathrm{PT}, \mathrm{UK}, \mathrm{SE}) \\
\text { - } & \text { Reducing traffic passing through } \\
& \text { urban streets by building bypass } \\
& \text { roads }(1-\mathrm{DE}) \\
\text { - } & \text { Improving local safety infrastructure } \\
& (1-\mathrm{FR}) \\
\text { - } & \text { Planning improvements for } \\
\text { pedestrians and cyclists }(1-\mathrm{UK}) \\
\text { - Separating vehicle traffic from bicycle } \\
\text { traffic }(1-\mathrm{SE}) \\
\text { - } \\
\text { crrangements of pedestrian } \\
\text { crossing }(1-\mathrm{SE})\end{array}$ & $\begin{array}{l}\text { Traffic calming in cities ( } 3 \text { - FI, PT, } \\
\text { CH) } \\
\text { Developing new guidelines for urban } \\
\text { roads ( } 1 \text { - DE) } \\
\text { - Limiting speeds in cities to } 40 \mathrm{~km} / \mathrm{h} \\
\text { where bicycle and pedestrian traffic } \\
\text { is not separated from vehicle traffic } \\
(1-\mathrm{FI}) \\
\text { - Arranging } 30 \mathrm{~km} / \mathrm{h} \text { zones near } \\
\text { schools and shopping centers ( } 1 \text { - } \\
\text { UK) }\end{array}$ \\
\hline
\end{tabular}

5.3 Efficiency estimates of interventions implemented by the NRSPs

The study sought for measures and activities associated with recent declines in road injury in the leading countries. Concerning the efficiency estimates of safety measures, it is worth noting that the safety literature includes many findings of evaluation studies that examined the safety effects of individual measures/interventions such as: specific infrastructure improvements; treatment of certain sites or selected populations; enforcement operations; changing regulations, etc. Those findings can be found in Elvik et al's book [12] as well as in reports, such as: ROSEBUD [41], Harkey et al. [23] and others. However, the evaluations of safety measures presented in those sources were not conducted as part of the countries' national programs and therefore, beyond a general knowledge that specific measures are associated with significant reductions in accidents/injuries, they cannot provide clear evidence of a link between the implementation of measures and recent reductions in the number of fatalities/accidents reported by the leading countries. Thus, a review of NRSPs and related publications was undertaken focusing on evidence of the efficiency assessments of interventions implemented during the NRSPs' performance in the countries considered. Such evidence was obtained mostly through evaluation studies conducted by major research institutes, during the implementation of the programs.

The evidence on efficiency of safety interventions was collected in several terms, which are: reductions in road traffic injuries and accidents; positive changes in road user behaviours, and high benefit-to-cost ratios in the economic evaluations conducted. In addition, findings were gathered regarding the scope of implementation of various interventions in the countries reviewed which could serve as an indirect indication of treatment's contribution to the program success. Tables 1 and 2 provide examples of findings, in terms of accident reductions associated with the measures implemented by the NRSPs and the scope of their implementation, respectively.
It was seen that, in general, findings regarding their safety effectiveness were available for measures belonging mostly to the areas of infrastructure and enforcement of risky behaviors. Certain evidence was accumulated as to the estimated efficiency and/or significant implementation scopes of interventions such as traffic calming measures in urban areas; preventing head-on collisions on singlecarriageway roads through median barrier or rumble-strip installation; automatic speed enforcement; increase in screening alcohol checks on roadsides; massive introduction of passive vehicle safety devices (seat belt reminder, electronic stability control).

As to the efficiency assessment in terms of benefit-to-cost ratio, a comprehensive example was given by Elvik [11], who examined the reduction potential of interventions suggested for implementation by a new NRSP in Norway. Forty measures were found with a benefit-to-cost ratio over one, where among the most promising measures, in terms of the numbers of road fatalities and serious injuries to be saved, were, e.g., road lighting; vehicle-related safety measures such as intelligent speed adaptation, electronic stability control, air-bags, event recorder, seat-belt reminder, promoting higher-star vehicles according to the European New Car Assessment Programme (EuroNCAP); speed and drinkdriving enforcement.

\section{Applying the international experience to Israeli conditions}

\subsection{Identifying main safety problems in Israel}

The last stage of the study sought to select, from the safety interventions that were proven effective in other countries, those that fit Israel's needs. To perform this task, three steps were undertaken: (a) identifying safety problems which are characteristic of the country; (b) examining the interventions that were implemented in the ten countries for addressing similar problems; (c) drawing recommendations regarding the interventions required to promote road safety in Israel. 
Table 1 Efficiency of interventions implemented by the NRSPs in reducing the number of road traffic injuries or accidents: examples

\begin{tabular}{|c|c|c|c|}
\hline & Measure/intervention & Country [source] & $\begin{array}{l}\text { Reported reduction in the numbers } \\
\text { of road traffic injuries or accidents }\end{array}$ \\
\hline 1 & $\begin{array}{l}\text { Infrastructure: urban streets - reducing travel } \\
\text { speed in cities by expanding } 30 \mathrm{~km} / \mathrm{h} \text { zones }\end{array}$ & The Netherlands [43] & $27 \%$ reduction in injuries \\
\hline 2 & $\begin{array}{l}\text { Infrastructure: rural single-carriageway roads - } \\
\text { median guardrails, mostly of steel cables (" } 2+1 \text { ", } \\
\text { " } 1+1 \text { " roads) }\end{array}$ & Sweden [26] & $\begin{array}{l}\text { Risk of fatal or serious accidents } \\
\text { was reduced by } 75 \%-80 \%\end{array}$ \\
\hline 3 & $\begin{array}{l}\text { Infrastructure: rural single-carriageway roads - } \\
\text { overtaking lanes and median guardrails (" } 2+1 \text { ", } \\
\text { " } 2+2 \text { " roads) }\end{array}$ & Finland [30] & $\begin{array}{l}\text { Treatment of } 130-200 \mathrm{~km} \text { reduces } \\
2-4 \text { fatalities per year }\end{array}$ \\
\hline 4 & $\begin{array}{l}\text { Infrastructure: rural single-carriageway } \\
\text { roads - rumble stripes in the middle }\end{array}$ & Finland [30] & $\begin{array}{l}\text { Fatal head-on collisions were } \\
\text { reduced by } 10 \%-20 \%\end{array}$ \\
\hline 5 & $\begin{array}{l}\text { Behaviors: speeding - enforcement by } \\
\text { fixed cameras at hazardous locations }\end{array}$ & Sweden [14] & $\begin{array}{l}70 \% \text { reduction in fatalities, } 40 \% \\
\text { reduction in injuries }\end{array}$ \\
\hline 6 & Behaviors: speeding_enforcement by fixed cameras & United Kingdom [35] & $\begin{array}{l}40 \% \text { reduction in fatalities and serious } \\
\text { injuries at locations with cameras }\end{array}$ \\
\hline 7 & Behaviors: speeding_enforcement by fixed cameras & France [35] & $\begin{array}{l}\text { Explains } 75 \% \text { of reduction in the number } \\
\text { of fatalities in the years } 2002-2005\end{array}$ \\
\hline 8 & $\begin{array}{l}\text { Behaviors: driving under the influence of alcohol- } \\
\text { enforcement by random checks }\end{array}$ & Sweden [2] & $\begin{array}{l}\text { The increase in the number of checks led } \\
\text { to annual savings of } 15-20 \text { fatalities } \\
\text { and of } 150-200 \text { serious injuries }\end{array}$ \\
\hline
\end{tabular}

In general, in order to identify typical safety problems for a specific country, a comprehensive in-depth analysis of the safety state in the country is required, including transportation, economic and social background data, examination of overtime progress and performing international comparisons. Such analysis should usually be performed as a basis for development of a national safety program [34]. At the time of the study's performance, such document was lacking for Israel. Thus, the study applied "substitutes" of such a document, in the form of research reports, information and knowledge summaries and other documents, recently published, which highlighted Israel's safety problems.

Table 2 Implementation scope of interventions in the NRSPs: examples

\begin{tabular}{|c|c|c|c|}
\hline & Measure/intervention & Country [source] & Implementation scope \\
\hline 1 & $\begin{array}{l}\text { Infrastructure: urban streets—reducing } \\
\text { travel speeds by expanding } \\
30 \mathrm{~km} / \mathrm{h} \text { zones }\end{array}$ & The Netherlands [26] & $\begin{array}{l}\text { From } 1998 \text { to } 2008 \text {, the share of } 30 \mathrm{~km} / \mathrm{h} \text { streets in the cities } \\
\text { increased from } 15 \% \text { to } 70 \% \text {. }\end{array}$ \\
\hline 2 & $\begin{array}{l}\text { Infrastructure: single — carriageway } \\
\text { roads - median guardrails' installation }\end{array}$ & Sweden [26] & $\begin{array}{l}\text { At the end of 2008: about } 2000 \mathrm{~km} \text { of roads were with median } \\
\text { guardrails (" } 2+1 \text { ", " } 1+1 \text { " roads). }\end{array}$ \\
\hline 3 & $\begin{array}{l}\text { Infrastructure: building bypasses to } \\
\text { avoid traffic passing through cities }\end{array}$ & Germany [35] & $\begin{array}{l}\text { In } 2001-2005,212 \text { bypasses were opened for traffic; at the end } \\
\text { of } 2005,88 \text { bypasses were under construction. }\end{array}$ \\
\hline 4 & Behaviors: speed enforcement & France $[4]$ & $\begin{array}{l}\text { At the end of } 2005 \text {, every driver was checked, on average, } \\
\text { seven times a month by fixed cameras. }\end{array}$ \\
\hline 5 & Behaviors: speed enforcement & The Netherlands [26] & $\begin{array}{l}\text { In } 2001-2007 \text {, the number of speed checks using fixed } \\
\text { cameras increased by } 3.5 \text { times. }\end{array}$ \\
\hline 6 & Behaviors: speed enforcement & Sweden [26] & $\begin{array}{l}\text { At the end of } 2008 \text {, almost } 1000 \text { cameras were installed } \\
\text { covering more than } 2700 \mathrm{~km} \text { of roads. }\end{array}$ \\
\hline 7 & Behaviors: seat-belts use-enforcement & The Netherlands [26] & $\begin{array}{l}\text { In } 2001-2007 \text {, the number of regional police checks for } \\
\text { detecting such offenses increased by } 2.2 \text { times. }\end{array}$ \\
\hline 8 & $\begin{array}{l}\text { Behaviors: driving under the influence } \\
\text { of alcohol—weekend enforcement }\end{array}$ & Belgium [15] & $\begin{array}{l}\text { In } 2003-2004 \text {, the number of breath tests conducted on main } \\
\text { and national roads increased by } 25 \% \text {. }\end{array}$ \\
\hline 9 & $\begin{array}{l}\text { Behaviors: driving under the influence } \\
\text { of alcohol-enforcement }\end{array}$ & Sweden [13] & $\begin{array}{l}\text { In } 2006,2.2 \text { million breath tests were conducted: on average, a } \\
\text { test per } 2.6 \text { drivers. }\end{array}$ \\
\hline 10 & Vehicle: electronic stability control (ESC) & Sweden [13] & In $2006,91 \%$ of new vehicles were equipped with ESC. \\
\hline 11 & Vehicle: seat-belt reminders & Sweden [13] & In $2006,80 \%$ of new vehicles were equipped with a reminder. \\
\hline
\end{tabular}


It is worth mentioning that in the literature no formal definition of a country's "main" (or typical, important) safety problems exists. Based on Elvik et al. [12], Jost et al. [28] and similar, to identify essential safety problems for Israel several criteria were suggested, such as: (1) identifying high-risk populations in the country, for which the risk of accident/injury occurrence related to exposure, or injury severity, is significantly higher than that for the entire population; (2) recognizing problematic safety issues based on international comparisons, where Israel was ranked low compared to the advanced countries; (3) a safety problem that has increased recently and/or may worsen in the coming years, where the estimates are received by means of the first two criteria, i.e. in terms of relative risk or international comparisons.

Thus, identification of the main safety problems for Israel was based on screening comparisons provided by international organizations such as ETSC [16], Jost et al. [28]; OECD/ECMT [35]; IRTAD [26], as well as research studies recently conducted in the country that focused on mapping traffic injury characteristics (e.g. [40]) and/or examined selected safety problems, e.g. pedestrian injury [21], alcohol-impaired driving [27], young drivers' involvements in accidents [29]. In addition, results of national surveys of travel speeds, seat-belt use, pedestrian behaviour at crosswalks and other traffic behaviours were considered as well as road safety related policy documents recently published in the country (e.g. [6]).

Based on the sources reviewed, as main safety problems for Israel were recognized: (1-4) Vulnerable road users: pedestrians, motorcyclists, children, the elderly; (5) Young drivers; (6-8) Unsafe behaviours: non-use of seat belts and child restraints in cars, driving under the influence of alcohol, speeding; (9-10) Infrastructure: lack of safety on urban streets and on rural single-carriageway roads; (11) Vehicles: low implementation of passive-safety measures; (12) Safety management: distribution of tasks and cooperation between authorities.

Furthermore, the safety problems characteristic for Israel were compared with major safety problems found in the leading countries (see Fig. 4). Accounting for the number of countries which dealt with similar problems during the last decade or announced them in the updated NRSPs, it was found that eleven Israeli problems are shared with the majority of countries, while one problem-pedestrian injuryis common to Israel and to half of the countries.

On the other hand, safety problems which were found as common by many leading countries, but were not included in the list of main Israeli problems were, e.g., cyclists; drivers with repeated offenses; professional drivers; failure to comply with traffic laws; driving under the influence of drugs/medications; design guidelines issues; roadside obstacles; vehicle maintenance problems; special safety measures for heavy vehicles; arrival time of rescue services on the accident scene. Among the reasons for not emphasizing these problems in Israel can be mentioned: (a) low problem exposure - for example, minority of cyclists in Israel by the end of the last decade led to relatively small injury numbers, but not necessarily due to their low injury risk; (b) absence of data regarding the problem scope-for example, it was not examined yet which share of drivers involved in road accidents were under the influence of drugs/medications; (c) absence of research results which would provide evidence concerning the problem's importance for local conditions.

However, it was noted that most of the problems left out of the list of important problems in Israel, did not receive high priority for treatment in the list of recommended interventions for promoting road safety in the EU countries, according to a policy paper published recently [10].

\subsection{Drawing recommendations for implementing safety interventions in Israel}

For each safety problem identified for Israel, a list of safety interventions and measures applied for addressing this issue, in other countries, was examined. The interventions which were actually applied in other countries and, thus, contributed to the success of these countries in reducing road traffic casualties, were recommended for implementation in Israeli conditions, yet accounting for local experience.

For example, one of safety problems identified in Israel and shared by the majority of countries was motorcyclists as vulnerable road users. In Israel, the risk of being killed as a motorcyclist is 16.9 times higher than for a vehicle driver, although, this risk in Israel is so far below the EU average [16]. In Israel, similar to the leading countries, the number of motorcyclist fatalities remains stable or even rises over the years, in contrast to the reduction in the number of fatalities among other road users. Although motorcyclists' safety problem is prominent in Israel, like in most countries, the number of interventions implemented so far is relatively small. Measures applied in Israel and in some of the ten countries are: obligatory helmet wearing, installing safety guardrails on roadsides. Additional measures that are not implemented yet in Israel, but applied in some of the ten countries and, also, are recommended for implementation in the EU are [10, 16, 42]: installation of motorcycle-friendly guardrails on new roads and in dangerous locations of existing roads; promoting graduated driving licensing for motorcyclists; raising the minimum age for receiving a motorcycle license; initiatives to install Anti-lock Braking Systems, automatic daytime running lights, speed limiters on motorcycles; educating motorcyclists on ways for improving their visibility and driving during congestion hours; 
speed enforcement of motorcyclists; improving road maintenance according to the needs of powered two-wheelers.

Concerning the problem of alcohol-impaired driving, it was indicated that similar to measures undertaken by leading countries, enforcement activities on the issue rose in Israel over the last years, e.g. from 4 to 69 road-side checks per 1000 population [17]. In addition, strengthening of punishment sanctions, including on-site license withdrawal and vehicle confiscation, was introduced in 2008, while publicity campaigns on drink-driving issues are also common in Israel, similar to other countries. Among the measures applied in some of the ten countries but not yet implemented in Israel appeared: regulations on lower alcohol thresholds for selected driver populations, e.g. young and heavy-vehicle drivers.

Similar summaries were provided for each one of the remainder main safety problems identified for Israel [20].

\section{Discussion}

This study aspired to apply a systematic approach for consideration and comparison of national road safety programs applied, over the last decade, by leading road safety countries. The experience of these countries was analyzed aiming to apply this knowledge for a better understanding of needs and gaps of an additional country-Israel, which was expected to benefit from the international experience while selecting more effective road safety interventions.

The best safety-performing countries were selected using a traditional way of comparing safety levels of countries by means of general safety indicators - numbers of fatalities per population, vehicle fleet and kilometers-traveled, which were complemented by a "progress" indicator of the average annual percentage change in fatalities, for a certain period. Moreover, as Israel frequently belongs to the groups of relatively good-performing countries, whereas the intention is to learn from "better examples", the leading countries were selected compared to Israel's position according to each one of the indicators considered. Only a few countries were found with better achievements according to all the indicators examined (Switzerland, Germany, the Netherlands), while the majority of countries selected demonstrated a better position according to some of the indicators.

The study undertook a detailed review of the national road safety programs of best-performing countries aiming to summarize their experience, both in terms of main safety issues, dealt with during the past decade, and the measures/ interventions applied for addressing them. As a result, detailed classifications of safety problems and measures/interventions implemented by the countries' programs were produced providing a background for addressing similar issues in any other country.
Additional publications were examined searching for evidence of the efficiency assessments of interventions implemented during the NRSPs' performance in the countries considered. The evidence on efficiency of safety interventions was found mostly in terms of reductions in traffic injuries or accidents, positive changes in road user behaviours, and/or essential scopes of implementation of some interventions. In general, the findings regarding their effectiveness were available, mostly, for measures belonging to the areas of infrastructure and enforcement of risky behaviors.

Furthermore, the study summarized the main safety problems for Israel, based on research reports, international comparisons and other documents, which identified highrisk population groups, pointed out problematic safety issues in Israel compared to other countries or indicated safety problems that increased recently or may worsen in the coming years. The detailed summaries of safety interventions adopted by the leading countries were examined for addressing similar problems in Israeli conditions.

The study demonstrated a high similarity of main safety problems characteristic for the majority of leading countries (and for Israel). The safety interventions which contributed to the countries' road safety progress in the last decade mostly came from the well-recognized areas of traffic calming, automatic speed enforcement, separating traffic directions on single-carriageway roads, etc., proving the efficiency of those measures also in the scope of implementing NRSPs. In addition, the study provided empirical summaries of measures, which were implemented or are suggested (sometimes, repeatedly) for implementation by the countries, which can be considered as the lists of interventions potentially applicable for treating certain safety problems. On the other hand, the findings demonstrated that for some common safety problems, e.g. motorcyclist injury, driving under the influence of drugs/medications, driving fatigue or elderly population vulnerability, prominent solutions are lacking, where the leading countries actually suggest considering various safety interventions on those matters.

The study's findings can serve as a basis for developing a new national program for promoting road safety in Israel or other countries. However, in order to assess the measures' potential for improving road safety in a country, it is recommended to perform a quantitative benefit-cost assessment, similar to that carried out by Elvik [11] for a new NRSP in Norway.

Acknowledgements This research was supported by the Israel National Road Safety Authority and the Research Fund on Insurance Matters, affiliated with the Israel Insurance Association.

Open Access This article is distributed under the terms of the Creative Commons Attribution License which permits any use, distribution and reproduction in any medium, provided the original author(s) and source are credited. 


\section{References}

1. Aarts LT, Weijermars WAM, Schoon CC \& Wesemann P (2008) A maximum of 500 road deaths in 2020: why not? Measures and effect estimates aimed at achieving a more ambitious road safety target (SWOV Report R-2008-5). Leidschendam, the Netherlands: SWOV Institute for Road Safety Research

2. Breen J, Howard E, Bliss T (2008) An independent review of road safety in Sweden. Swedish Road Administration

3. Bliss T, Breen J (2009) Implementing the Recommendations of the World Report on Road Traffic Injury Prevention. Country Guidelines for the Conduct of Road Safety Capacity Reviews and the Related Specification of Lead Agency Reforms, Investment Strategies and Safety Projects. World Bank Global Road Safety Facility, Washington, DC

4. Chapelon J (2006) Trends in France. European Transport Conference 2006. Association for European Transport, London

5. Christoph MWT (2010) Estimate of the safety effects of intelligent vehicle systems; A literature study (SWOV Report R-2010-8). SWOV Institute for Road Safety Research, Leidschendam, the Netherlands

6. Committee (2005) Report of expert committee appointed by the Minister of Transport for preparing perennial national safety program. Jerusalem: Ministry of Transport. http://rsa.gov.il/SiteCollectionDocuments/shyninReport.pdf. Accessed 20 June 2009

7. COWI (2010) European Commission DG-TREN; Technical Assistance in support of the Preparation of the European Road Safety Action Programme 2011-2020. Denmark: COWI. Accessed 20 July $2010 \mathrm{http}: / /$ ec.europa.eu/transport/road_safety/pdf/ prepar_ersap_final_report.pdf

8. Derriks HM and Mak PM (2007) Underreporting of road traffic casualties. (IRTAD special report). Paris: The International Transport Forum, Organisation for Economic Co-operation and Development

9. EC [European Commission] (2003) European Road Safety Action Programme: Halving the number of road accidents victims in the European Union by 2010: A shared responsibility. (Document COM (2003) 311 final). Brussels: Commission of the European Communities

10. EC [European Commission] (2010). Road Safety Programme 2011-2020: detailed measures. (Document MEMO/10/343). Brussels: European Commission

11. Elvik R (2008) Road Safety Management by Objectives: A Critical Analysis of the Norwegian Approach. Accident Analysis and Prevention 40:1115-1122

12. Elvik R, Hoye A, Vaa T, Sorensen M (2009) The Handbook of Road Safety Measures. Emerald Group Publishing, Bingley

13. Elvik R, Kolbenstvedt M, Elvebakk B, Hervik A, Braein L (2009) Costs and benefits to Sweden of Swedish road safety research. Accident Analysis and Prevention 41(3):387-392

14. ETSC [European Transport Safety Council] (2006) A Methodological Approach to National Road Safety Policies. Brussels: Author

15. ETSC [European Transport Safety Council] (2006) Traffic Law Enforcement across the EU. Brussels: Author

16. ETSC [European Transport Safety Council] (2008) Vulnerable Riders - Safety Implications of Motorcycling in the European Union. Brussels: Author

17. ETSC [European Transport Safety Council] (2010) Tackling the three main killers on the roads. A priority for the forthcoming EU Road Safety Action Programme. PIN Flash n.16. Brussels: Author

18. Evans L (2004) Traffic Safety. Science Serving Society, Bloomfield Hills, Michigan

19. Gitelman V, Doveh E, Hakkert S (2010) Designing a composite indicator for road safety. Safety Science 48:1212-1224

20. Gitelman V, Hendel L, Carmel R, Bekhor S (2010). An examination of the national road-safety programs in ten world's leading countries in road safety. (Report S/15/2010, Ran Naor Road Safety Research Center). Haifa, Israel: Technion - Israel Institute of Technology

21. Gitelman V, Balasha D, Carmel R, Hendel L, Pesahov F (2010) Characterization of pedestrian accidents and an examination of infrastructure measures to improve pedestrian safety in Israel. Accident Analysis and Prevention. doi:10.1016/j.aap.2010.11.017

22. Hakkert AS and Gitelman V (1999) Development of a National Road Safety Program in Israel: Baseline, Components and Lessons. In: Proceedings of International Conference Traffic Safety on Two Continents (VTI konferens 13A, part 3: 75-92). Linkoping, Sweden: Swedish National Road and Transport Research Institute (VTI)

23. Harkey DL, Srinivasan R, Baek J, Council FM et al (2008) Accident modification factors for traffic engineering and ITS improvements. (National Cooperative Highway Research Program (NCHRP) Report 617). Washington, D.C., Transportation Research Board

24. Hufnagl G (2007) SUPREME: Summary and Publication of Best Practices in Road Safety in the Member States. European Transport Conference 2007. London: Association for European Transport

25. IRTAD [International Traffic Safety Data and Analysis Group] (1998) Definitions and Data Availability. (OECD-RTR Road Transport Research Programme Special Report). BergischGladbach, Germany: Federal Highway Research Institute (BASt)

26. IRTAD [International Traffic Safety Data and Analysis Group] (2009) IRTAD Annual Report 2009. Joint OECD/ITF Transport Research Centre, Paris

27. Jaffe DH, Savitsky B, Zaistev K, Hiss J, Peleg K (2009) Alcohol and Driver Fatalities in Israel: An Examination of the Current Problem. IMAJ 11:725-729

28. Jost G, Popolizio M, Allsop R, Eksler V (2009) 2010 on the horizon; 3rd road safety Performance Index PIN report. European Transport Safety Council, Brussels

29. Lotan T, Grimberg E (2008) Young drivers' involvement in road accidents: data, trends and research. Israel, Or Yarok (Green Light)

30. MTC [Ministry of Transport and Communications] (2006) Programmes and strategies 1/2006. Road Safety 2006-2010. Helsinki, Finland: MTC. Accessed 1 July 2009. http://www.lvm.fi/c/document_library/get_file?folderId=22167\&name=DLFE-6008.pdf

31. Ministry of Transport, Public works and Water Management (2009) Road Safety Strategic Plan 2008-2020. Den Haag, the Netherlands: Author

32. Muhlrad N (2009) Road safety management systems, a comprehensive diagnosis method adaptable to low and middle income countries (Synthèse INRETS n59). INRETS, Arcueil, France

33. Muhlrad N, Gitelman V \& Buttler I (Eds) (2011) Road safety management investigation model and questionnaire. Deliverable 1.2 of the EC FP7 project DaCoTA

34. OECD [Organisation for Economic Co-operation and Development] (2002) Safety on the roads: What's the vision? OECD Publishing, Paris

35. OECD/ECMT [Organisation for Economic Co-operation and Development/European Conference of Ministers of Transport] (2008) Country reports on road safety performance. OECD/ECMT working group on achieving ambitious road safety targets. Paris: Joint OECD/ECMT Transport Research Centre. Accessed 5 July 2009 http://www.internationaltransportforum.org/jtrc/safety/targets/ Performance/performance.html

36. OECD/ITF [Organisation for Economic Co-operation and Development/International Transport Forum] (2008) Towards Zero-Ambitious Road Safety Targets and the Safe System Approach. Paris: Author

37. OECD/ITF [Organisation for Economic Co-operation and Development/International Transport Forum] (2011) IRTAD Annual Report 2010. International Traffic Safety Data and Analysis Group. Paris: Author

38. Peden M, Scurfield R, Sleet D, Mohan D, Hyder AA, Jarawan E, Mathers C (eds) (2004) World Report on Road Traffic Injury Prevention. World Health Organization, Geneva 
39. PIARC [World Road Association] (2003) Road Safety Manual. Recommendations from the World Road Association. CanadaQuebec: Route Market

40. Prato GC, Gitelman V, Bekhor S (2010) Mapping patterns and characteristics of fatal road accidents in Israel. In: Proceedings of the $12^{\text {th }}$ World Congress on Transport Research (WCTR). Lisbon, Portugal: WCTR

41. ROSEBUD [Road Safety and Environmental Benefit-Cost and Cost-Effectiveness Analysis for Use in Decision-Making] (2003) Screening of Efficiency Assessments Experiences-Report "State of the Art". (ROSEBUD Report D2). Bergisch-Gladbach, Germany: Federal Highway Research Institute (BASt)

42. SWOV [Institute for Road Safety Research] (2009) Motorcyclists. SWOV Fact sheet. Leidschendam, the Netherlands: Author

43. Wegman FCM and Aarts LT (Eds) (2006) Advancing sustainable safety: national road safety outlook for 2005-2020. Leidschendam, the Netherlands: SWOV Institute for Road Safety Research.
44. Wegman F, Commandeur J, Doveh E, Eksler V, Gitelman V, Hakkert S, Lynam D, Oppe S (2008) SUNflowerNext: Towards a Composite Road Safety Performance Index. SWOV Institute for Road Safety Research, Leidschendam, the Netherlands

45. Weijermars WAM, Goldenbeld Ch, Bos NM, Bijleveld FD (2008) Road safety in 2007: is a standstill a step backwards? Analysis of crashes, mobility, behaviour and policy (SWOV Report R-200812). SWOV Institute for Road Safety Research, Leidschendam, the Netherlands

46. Wijnen W, Mesken J, Vis MA (2010) Effectiveness and costs of road safety measures (SWOV Report R-2010-9). SWOV Institute for Road Safety Research, Leidschendam, the Netherlands

47. Wilmots B, Hermans E, Brijs T, Wets G (2010) Setting up an indicator system for monitoring road safety using the road safety target hierarchy. In: Proceedings of the 15th International Conference Road Safety on Four Continents. Swedish National Road and Transport Research Institute, Linkoping, Sweden, pp 1154-1165 